\title{
Snellen Chart Based On Android Control
}

\author{
Annisa Novantina Eka Fitria\#, Priyambada Cahya Nugraha, Lamidi \\ Department of Electromedical Engineering Poltekkes Kemenkes, Surabaya \\ Jl. Pucang Jajar Timur No. 10, Surabaya, 60245, Indonesia \\ \#anisanovantina1@gmail.com, priyambadacn@gmail.com, justlamidi@yahoo.co.id
}

\begin{abstract}
Eye vision is a person's visual acuity examination that is usually done using a Snellen chart. The Snellen chart is a poster that contains a number of letters that are different on each line with the letters getting closer to the bottom lines. Eye vision examination using a normal Snellen chart is done at a distance of 6 meters because someone is considered normal if he is able to read on the 20/20 line in feet or 6/6 in meters. Snellen chart control android is an electronic Snellen chart that controls the light transfer using Android. Commands originating from the Mitapp application on android are sent to the Bluetooth HC-05 module in the min sys Atmega16 circuit. Atmega 16 was chosen because it has a sufficient number of pins to control the displacement of the lights used by 23 lights. The appearance of the MIT app application has been adjusted to the letters contained in the Snellen chart, making it easier for operator to correct the results of the readings that have been performed by the eye vision patient.
\end{abstract}

Keywords-; Eye Vision; Snellen Chart; Atmega 16; Bluetooth HC-05; Android

\section{INTRODUCTION}

Eye vision is eye sharpness or eye clarity. Visus is a measure, how far and detail an object can be caught by the eye so that visus can be called the most important eye physiology. Visual acuity is based on the principle of the existence of a minimum separation power which is the smallest distance between 2 lines that may still be separated and can be captured as 2 lines. The object of the actual eye examination was first introduced by Heinrich Kuechler (1811-1873) and corrected by an ophthalmologist from Vienna, Austria, Eduard Jager von Jaxtthal or better known as Jager, the initiator of a reading chart in 1854. In 1862 Snellen became the main examiner and at the same time, he introduced to the world the results of his work which was named Optotype.

The previous object Snellen in the form of 11 lines of letters in the form of capital letters. The first line consists of 1 uppercase letter, usually the letters are E, $\mathrm{H}$ and or $\mathrm{N}$. The next line is filled with more letters than before, except that the letters are reduced in size. The final assignment with Snellen chart was made before by Ristica Tyas Surya with the title "Snellen Chart Accompanied by Microcontroller Based Normal / Normal Visual Acuity Results", the tool still has a disadvantage of having a weakness in the connecting cable between the transmitter and the receiver which is prone to breakdown [1].

The next Snellen chart is made by Mardhiatus Sholihah entitled "Snellen Wireless Final Report with Double Chart Equipped with Patient Control (Wireless System)" [2]. In the same year, Snellen was also made by Satrio Hendra Yunianto entitled "Snellen Final Project Report with Double Chart Equipped with Patient Control (Motor Control and Switching of Lights)" [3]. The tool mentioned above also still has several disadvantages including sending data on the transmitter has a very long delay because the grounding on the transmitter circuit is not good. In addition, the lights on the largest letters are less bright, which is caused by the supply in the circuit drop so that the voltage for the lamp is less.

Based on the weaknesses of the tools that have been made before, namely the control of lamp selection is not practical, with reference to the weaknesses of these tools, the author intends to make a tool with the title "Snellen Chart Control Android" which develops Snellen chart reading technology with controls choosing lights using android with the aim of facilitating the visual inspection process of the eye.

\section{MATERIALS AND METHODS}

\section{A. Experimental Setup}

The study was conducted by operating the Snellen chart using Android as a control of the transfer of lights. Tests were carried out with the aim of knowing the ability of Bluetooth HC-05 to send data to android at a distance of 10 meters. Tests are also carried out to determine the accuracy of the button. The test is carried out with 2 conditions, namely the first condition in one room without a barrier while the second condition is different from the room with a change in range every 2 meters. Tests for each distance range are carried out 5 times.

\section{1) Materials and Tool}

This research uses Snellen charts and Android. The snellen chart is created by placing lights on each block of the Snellen chart that will light up when the button on the android is pressed. Atmega 16 microcontroller is used to provide logic in 2803 ULN lamp drivers and connect to android using Bluetooth HC-05. Mitapp application is used to send data from android to the Atmega 16 microcontroller.

2) Experiment 
In this study, the test was carried out with 2 conditions, namely the first condition in one room without a barrier while the second condition was different from the space with changes in the range every 2 meters with a distance limit of 10 meters between the transmitter (android) and receiver (Snellen chart). Tests on each distance range are carried out 5 times to determine the ability of the android connection to Bluetooth HC-05 and to know the accuracy of the button.

\section{B. The Diagram Block}

Turned ON the switching power, the power supply will supply voltage to the entire circuit. Android mobile will receive instructions from users and will send data to the receiver via Android Bluetooth. Data or information sent by Bluetooth android will then be received by the $\mathrm{HC} 05$ Bluetooth module to be processed by ATMega 16. Programmed 16 ATMega 16 is used to control 3 external 2803 lamp drivers that will turn on the LED lights according to instructions received from mobile phones android. The LED will be turned on or off by ATMega 16 using digital high or low voltage signals.

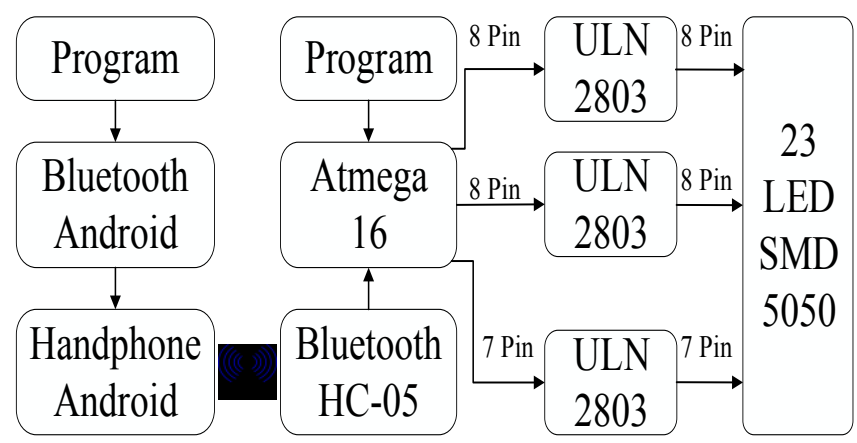

Fig. 1. The diagram block of the Snellen Chart

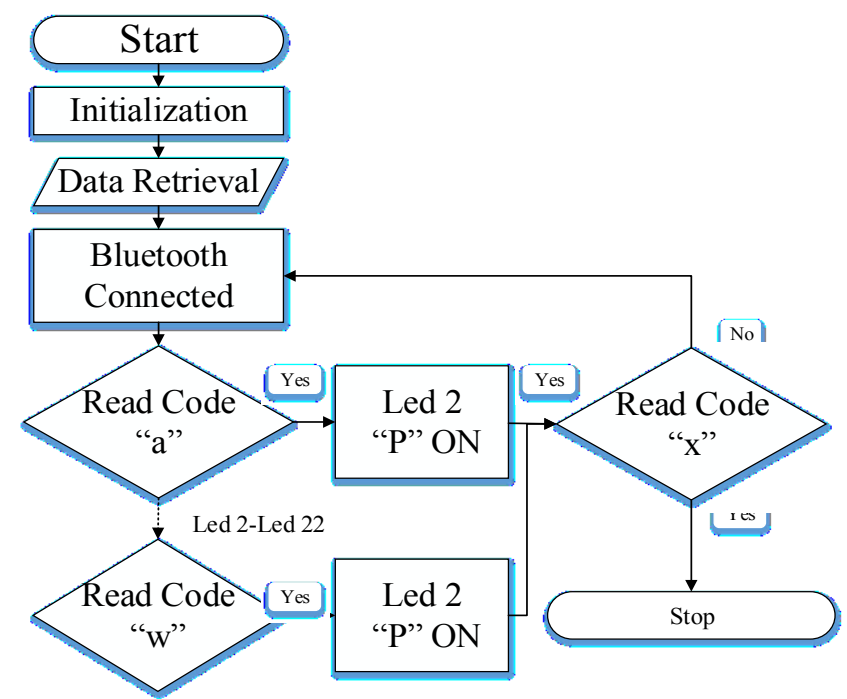

Fig. 2. The Flowchart of the Receiver

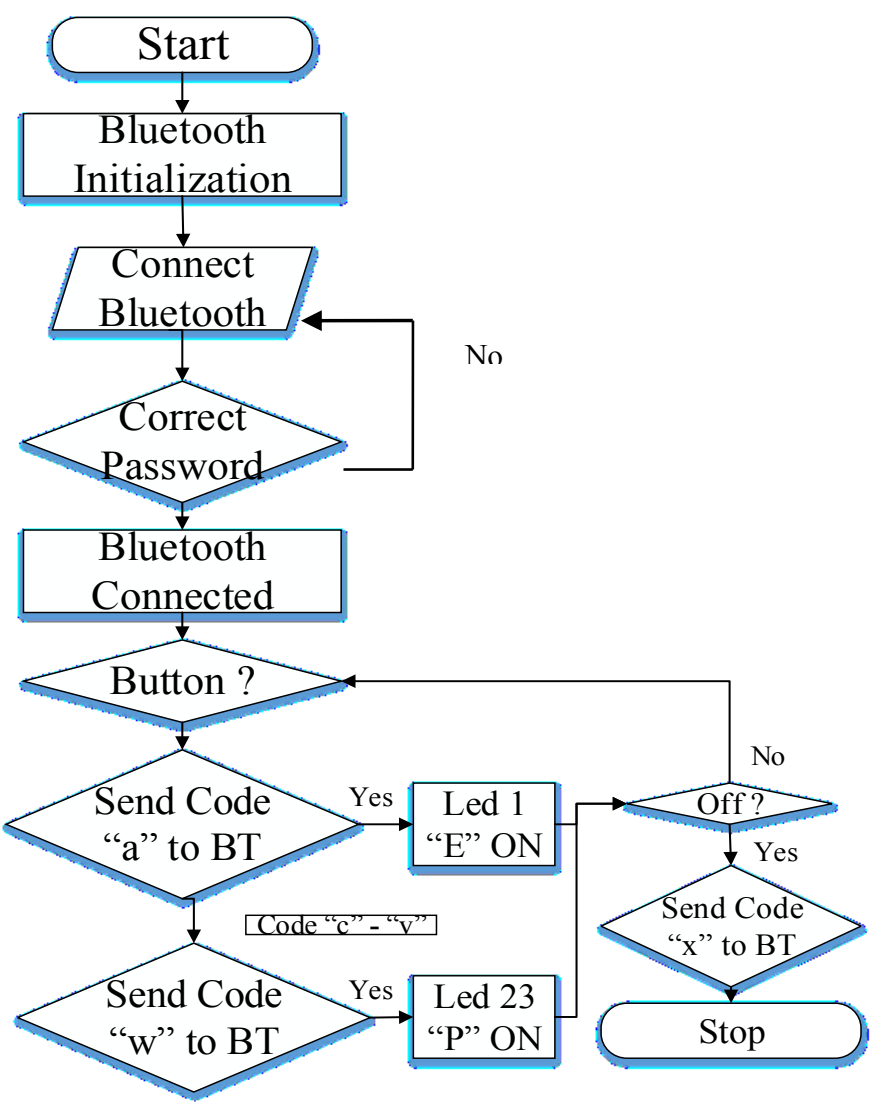

Fig. 3. The Flowchart of Transmitter

\section{The Flowchart}

The transmitter program is created based on the flow diagram as shown in Figure 2. After the initialization is done, the program detects whether the Bluetooth connection is active. If the password is wrong then it will return to the password settings and if it is true then Bluetooth android will be connected to the Bluetooth receiver $\mathrm{HC}-05$ and then ready to send data.

The receiver program is based on a flow chart as shown in Figure 3. When the device is turned on and Bluetooth HC-05 has been connected to android, the program will order to retrieve data from the transmitter, the program will read the code that instructs to switch the lights.

\section{The Circuit}

An important part of the design of this study is the minimum system circuit illustrated in Figure 4, and the ULN 2803 driver circuit in figure 5. The minimum system circuit is used to provide 2803 ED external logic used as the lamp driver.

\section{1) Minimum System}

The minimum system circuit as shown in figure 6 . The circuit consists of ATMega 16 which is adjusted to the number of pins that will be used as input to the 2803 ULN lamp driver. 
Foot $\mathrm{Rx}$ and $\mathrm{Tx}$ at the minimum system connected to Bluetooth HC-05.

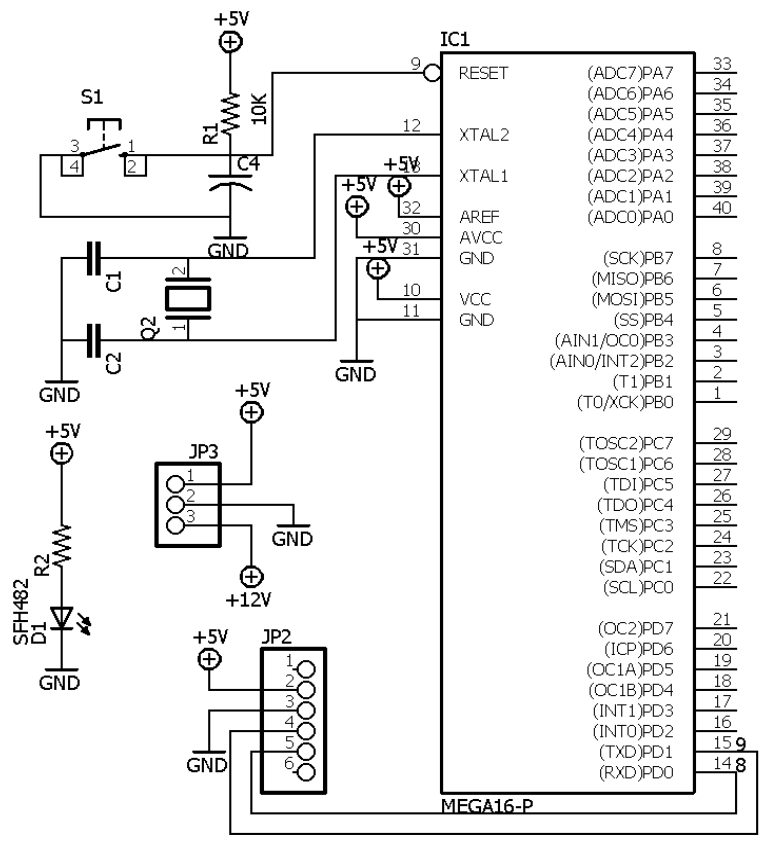

Fig. 4. Minimum System

\section{2) Driver ULN 2803}

In the lamp driver series, feet number 1 to 8 on 2803 are connected to ports on ATMega 16, foot number 9 is connected to ground, leg number 10 ULN 2803 is supplied with $12 \mathrm{~V}$ power, while legs 11 to $18 \mathrm{UL} 2803$ are connected to the lamp.

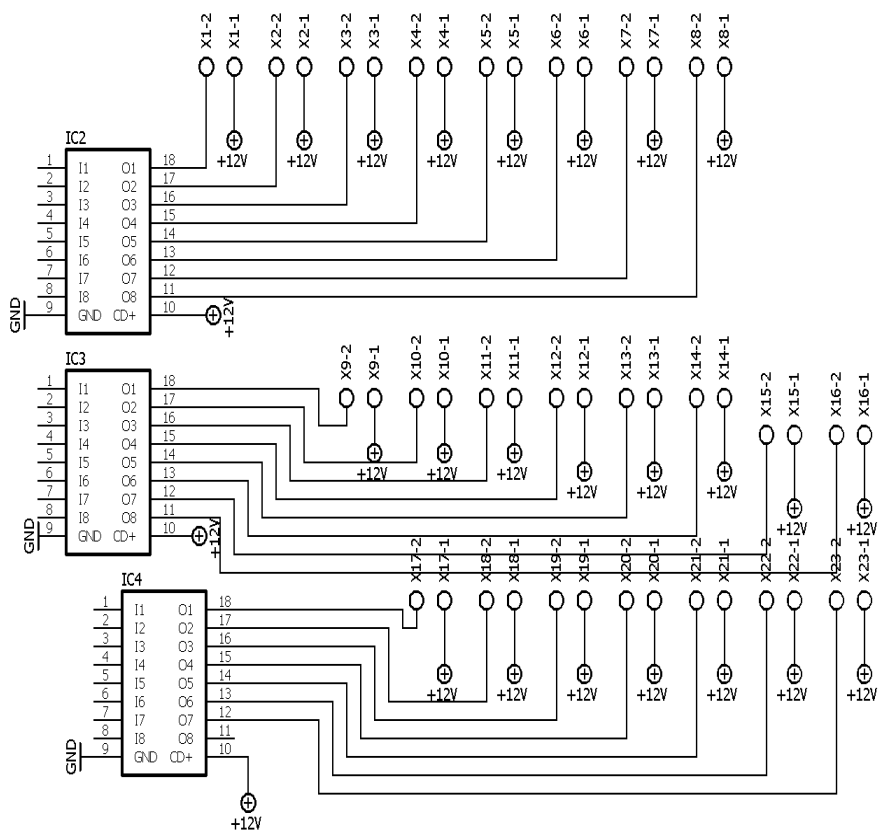

Fig. 5. Driver ULN 2803

\section{3) Bluetooth Module}

The process of sending data is done using Bluetooth and Android as the control server. Bluetooth used is Bluetooth HC-05. Bluetooth HC-05 will receive data sent by android and then the data will be processed by ATmega 16. Data that has been processed by ATMega 16 will control 2803 ULN lamp drivers.

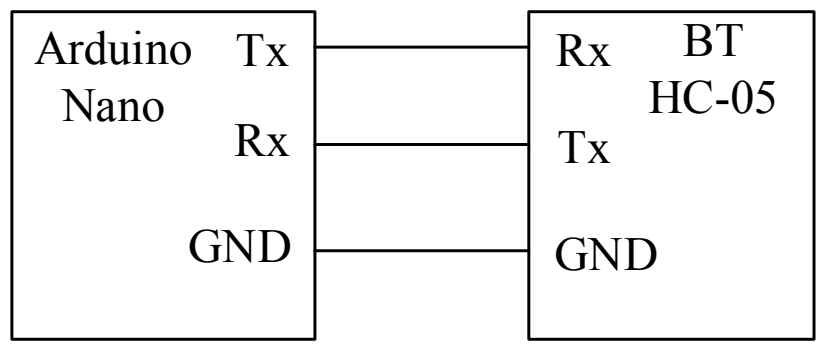

Fig. 6. Bluetooth Connection

\section{RESULTS}

Bluetooth distance testing is done to determine the ability of bluetooth HC-05 to send data to android at a distance of 10 meters. The test is carried out with 2 conditions, namely the first condition in one room without a barrier while the second condition is different from the room with a change in range every 2 meters. Tests for each distance range are carried out 5 times.

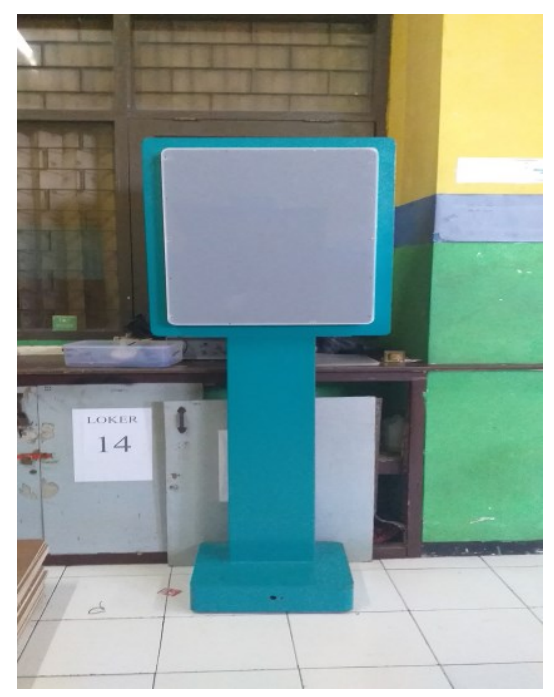

Fig. 7. The Snellen Chart design

\section{1) The Snellen Chart Design}

Fig. 7 is an analog part of the Snellen chart control android. The analog Snellen chart consists of ATMega 16, ULN 2803, and Bluetooth HC-05. ATMega 16 is a microcontroller that is used to process programs used to control ED 2803. The process of sending data is done using Bluetooth HC-05 and Android as a control server. Data that has been processed by ATMega 16 will control ED 2803 which functions as a lamp transfer driver. 
2) The Listing Program for Mitapp and Atmega 16

In this paper, the software is divided into two, namely for Android programming using the Mitapp application and Atmega 16 programming with Arduino.

Listing program 1. Android initialization

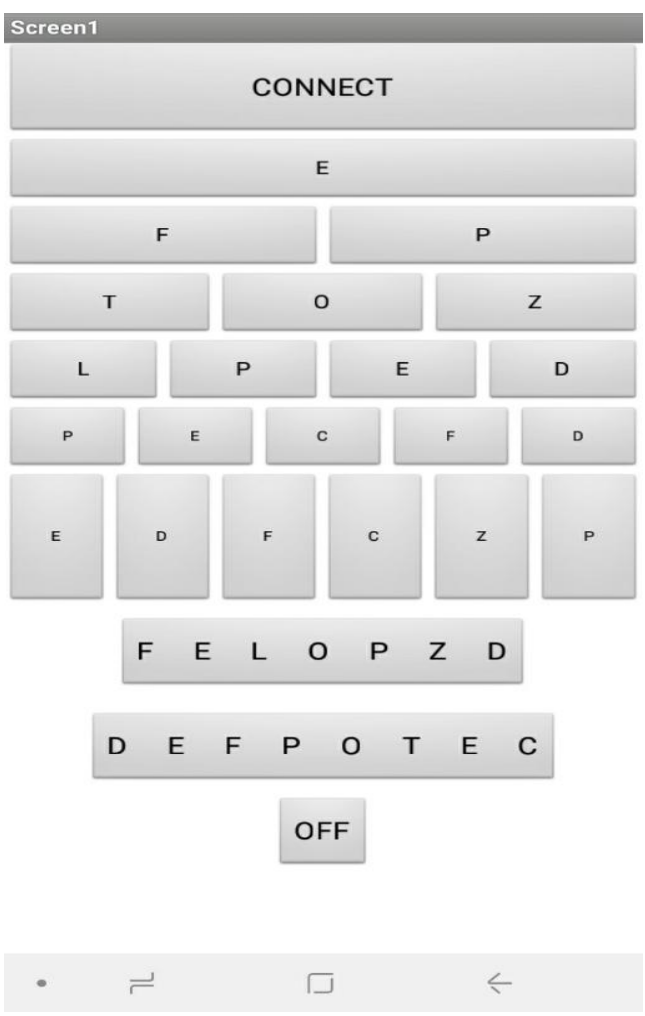

Fig. 8. App's Initial Display on Android

Fig. 8 is the initial appearance of the application on Android. Android will display buttons containing letters in accordance with the letters available on the Snellen chart.

Listing program 2. Bluetooth Initialization on Android

SNELEN
00:18:E4:34:ED:A7 HC-05
98:D3:41:F5:A5:00 SNELLEN
00:1A:7D:DA:71:06 WK-SERVER

Fig. 9. Bluetooth initialization on Android

Fig. 9 is a Bluetooth initialization on Android. If the android Bluetooth button is active then android will display "ListPicker" which contains the names of available Bluetooth. If the password is correct, Bluetooth will be connected
Listing program 3. Listing Program Bluetooth Connection

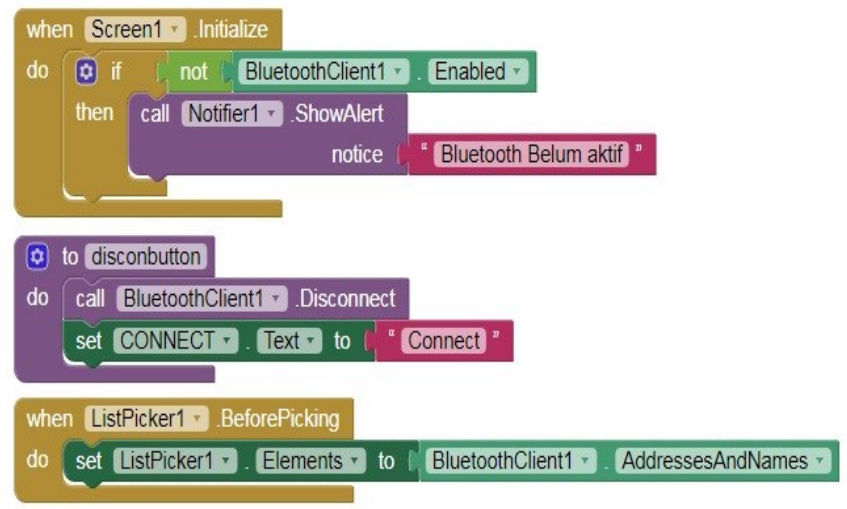

Fig. 10. Listing Program Bluetooth Connection

Fig. 10 is a Bluetooth connection program listing that is in the Mitapp application. Android will bring up a notification "Bluetooth is not active" if the Android Bluetooth has not been activated.

Listing program 4. Listing Program Bluetooth Connected or Not
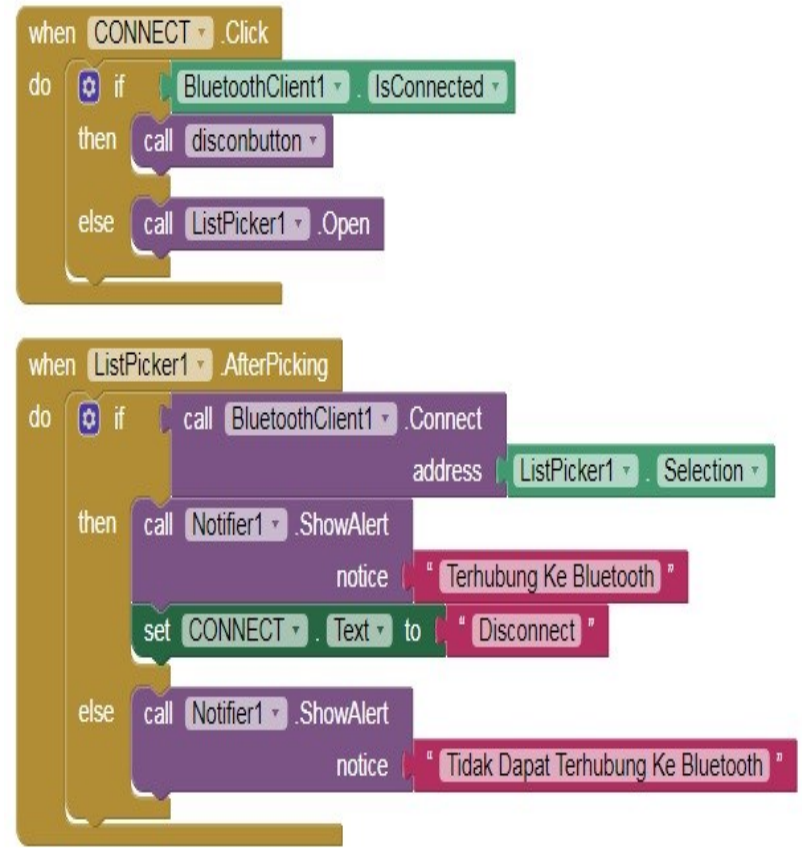

Fig. 11. Listing Program Bluetooth Connected or Not

Fig. 11 is a Bluetooth program listing connected or not. Android will display a notification "cannot connect to Bluetooth" if the password is incorrect. Android will bring up a notification "Connect to Bluetooth" if the password is correct. 
Listing program 5. Listing Lamp Selection

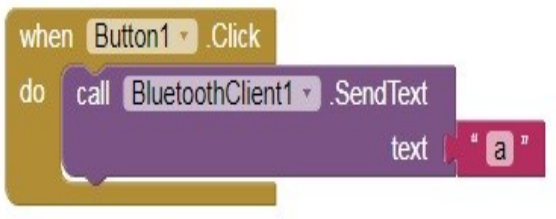

Fig. 12 Listing Lamp Selection

Fig. 12 is a program listing of lamp selection 1 . The button is pressed according to the selection of the lamp with the desired letter. In this application, there are 23 buttons that will turn on 23 different lights.

Listing program 6. Listing Program Turn Off The Lamp

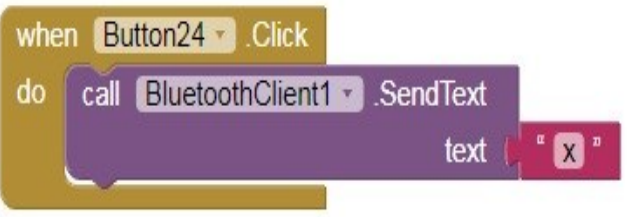

Fig. 13. Listing Program Turn Off The Lamp

Fig. 14 is a program listing to turn off lights. When the off button is pressed it will turn off the lights that are on.

\section{3) Listing Program Atmega 16 with Arduino}

Listing Program 6. Program Initialization

const int pin $1=31$; // Lampu 1

const int pin2 = 30; // Lampu 2

const int pin3 = 29; // Lampu 3

const int pin $4=28$; // Lampu 4

const int pin5 $=27$; // Lampu 5

const int pin $6=26$; // Lampu 6

const int $\operatorname{pin} 7=25$; // Lampu 7

const int pin $8=24$; // Lampu 8

const int $\operatorname{pin} 9=4$; / Lampu 9

const int $\operatorname{pin} 10=3$; // Lampu 10

const int pin $11=2$; // Lampu 11

const int pin $12=1$; // Lampu 12

const int pin $13=0 ; / /$ Lampu 13

const int pin $14=23$; // Lampu 14

const int pin $15=22$; // Lampu 15

const int $\operatorname{pin} 16=21$; // Lampu 16

const int $\operatorname{pin} 17=20 ; / /$ Lampu 17

const int $\operatorname{pin} 18=19$; // Lampu 18

const int pin $19=18$; // Lampu 19

const int pin $20=17$; / Lampu 20

const int $\operatorname{pin} 21=16$; / Lampu 21

const int $\operatorname{pin} 22=15$; / Lampu 22

const int pin $23=14$; // Lampu 23

int mulai $=0$;

char readSerial;
In the above program listing, "int" initialization is a numeric data type used when not dealing with fractions or decimals. "Const int" is a constant in the form of an integer that refers to the Arduino pinboard.

\begin{tabular}{|l} 
Listing Program 7. Program Setup \\
void setup() \{ \\
// put your setup code here, to run once: \\
pinMode (pin1, OUTPUT); \\
pinMode (pin2, OUTPUT); \\
pinMode (pin3, OUTPUT); \\
pinMode (pin4, OUTPUT); \\
pinMode (pin5, OUTPUT); \\
pinMode (pin6, OUTPUT); \\
pinMode (pin7, OUTPUT); \\
pinMode (pin8, OUTPUT); \\
pinMode (pin9, OUTPUT); \\
pinMode (pin10, OUTPUT); \\
pinMode (pin11, OUTPUT); \\
pinMode (pin12, OUTPUT); \\
pinMode (pin13, OUTPUT); \\
pinMode (pin14, OUTPUT); \\
pinMode (pin15, OUTPUT); \\
pinMode (pin16, OUTPUT); \\
pinMode (pin17, OUTPUT); \\
pinMode (pin18, OUTPUT); \\
pinMode (pin19, OUTPUT); \\
pinMode (pin20, OUTPUT); \\
pinMode (pin21, OUTPUT); \\
pinMode (pin22, OUTPUT); \\
pinMode (pin23, OUTPUT); \\
Serial.begin (9600); \\
\}
\end{tabular}

The program listing above is for setting up the setup tool, "Serial.begin" to set the data transmission speed, Pin1, Pin2, Pin3 to Pin23 set as Output.

\section{Listing Program 8. Data Retrieval}

void loop() \{

// put your main code here, to run repeatedly:

if (Serial.available())

\{

readSerial $=$ Serial. $\operatorname{read}()$;

\}

if $($ readSerial $==$ 'a' $)\{$

mulai $=1$;

\}

if $\left(\right.$ readSerial $\left.=={ }^{\prime} b '\right)\{$

mulai $=2$;

\}

if $($ readSerial $==$ 'w') 


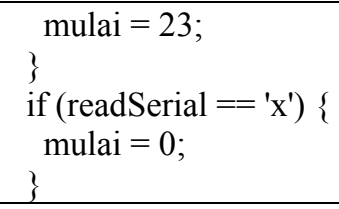

In the above program listing, "int" initialization is a numeric data type used when not dealing with fractions or decimals. "Const int" is a constant in the form of an integer that refers to the Arduino pinboard.

Listing Program 9. Listing Program Control Lamp

if $($ mulai $==0$ )

\{ digitalWrite (pin1, LOW); digitalWrite (pin2, LOW); digitalWrite (pin3, LOW); digitalWrite (pin4, LOW); digitalWrite (pin5, LOW); digitalWrite (pin6, LOW); digitalWrite (pin7, LOW); digitalWrite (pin8, LOW); digitalWrite (pin9, LOW); digitalWrite (pin10, LOW); digitalWrite (pin11, LOW); digitalWrite (pin12, LOW); digitalWrite (pin13, LOW); digitalWrite (pin14, LOW); digitalWrite (pin15, LOW); digitalWrite (pin16, LOW); digitalWrite (pin17, LOW); digitalWrite (pin18, LOW); digitalWrite (pin19, LOW); digitalWrite (pin20, LOW); digitalWrite (pin21, LOW); digitalWrite (pin22, LOW); digitalWrite (pin23, LOW); \}

if (mulai $==1)$

$\{$ digitalWrite (pin1, HIGH); digitalWrite (pin2, LOW); digitalWrite (pin3, LOW); digitalWrite (pin4, LOW); digitalWrite (pin5, LOW); digitalWrite (pin6, LOW); digitalWrite (pin7, LOW); digitalWrite (pin8, LOW); digitalWrite (pin9, LOW); digitalWrite (pin10, LOW); digitalWrite (pin1 1, LOW); digitalWrite (pin12, LOW); digitalWrite (pin13, LOW); digitalWrite (pin14, LOW); digitalWrite (pin15, LOW); digitalWrite (pin16, LOW);
digitalWrite (pin17, LOW); digitalWrite (pin18, LOW); digitalWrite (pin19, LOW); digitalWrite (pin20, LOW); digitalWrite (pin21, LOW); digitalWrite (pin22, LOW); digitalWrite (pin23, LOW); ?

From the above program, it can be seen that the code "start" is the selector of the selected lamp where there are numbers behind the code according to the lights to be turned on. The program consists of 23 light codes where the lamp will turn on when given HIGH logic on the Atmega 16 pin.

\section{4) Bluetooth Accuracy Test}

Bluetooth distance testing is done to determine the ability of Bluetooth HC-05 to send data to android at a distance of 10 meters. The test is carried out with 2 conditions, namely the first condition in one room without a barrier while the second condition is different from the room with a change in range every 2 meters. Tests for each distance range are carried out 5 times.

TABLE I. MEASUREMENT RESULTS IN A NON-BARRIER ROOM

\begin{tabular}{cc}
\hline Distance $(\mathrm{m})$ & Error $(\%)$ \\
\hline 2 & 0 \\
4 & 0 \\
6 & 0 \\
8 & 0 \\
10 & 0 \\
\hline
\end{tabular}

Based on the data above, it can be seen that each measurement is carried out 5 times with a change in the distance range every 2 meters. Measurements are carried out in one room without a barrier. In measurements with a distance of 2 meters, the results are obtained if the error value is 0 . The second measurement at a distance of 4 meters error value of $0 \%$. The third measurement at a distance of 6 meters error value of $0 \%$. Measurement of the fourth error value is $0 \%$ while the fifth measurement error value is $0 \%$.

TABLE II. MEASUREMENT RESUlts TABLE IN A BARRIER ROOM

\begin{tabular}{cc}
\hline Distance $(\mathrm{m})$ & Error $(\%)$ \\
\hline 2 & 0 \\
4 & 0 \\
6 & 0 \\
8 & 0 \\
10 & 0 \\
\hline
\end{tabular}

Based on the data above, it can be seen that each measurement is carried out 5 times with a change in the distance range every 2 meters. Measurements are carried out in a room with a barrier. In measurements with a distance of 2 
meters, the results are obtained if the error value is 0 . The second measurement at a distance of 4 meters error value of $0 \%$. The third measurement at a distance of 6 meters error value of $0 \%$. Measurement of the fourth error value is $0 \%$ while the fifth measurement error value is $0 \%$.

The accuracy of the button is done to find out the Bluetooth response of $\mathrm{HC}-05$ to receive data from Android according to the emphasis button on Android. Tests are carried out at a distance of 6 meters according to the standard eye vision examination. Tests are carried out 5 times for each light switch.

TABLE III. THE RESULTS OF THE BUTTON ACCURACY TEST

\begin{tabular}{cc}
\hline Tombol & Akurasi (\%) \\
\hline LED 1 "E" & 100 \\
LED 2 "P" & 100 \\
LED 3 "F" & 100 \\
LED 4 "Z" & 100 \\
LED 5 "O" & 100 \\
LED 6 "T" & 100 \\
LED 7 "D" & 100 \\
LED 8 "E" & 100 \\
LED 9 "P" & 100 \\
LED 10 "L" & 100 \\
LED 11 "D" & 100 \\
LED 12 "F" & 100 \\
LED 13 "C" & 100 \\
LED 14 "E" & 100 \\
LED 15 "P" & 100 \\
LED 16 "P" & 100 \\
LED 17 "Z" & 100 \\
LED 18 "C" & 100 \\
LED 19 "F" & 100 \\
LED 20 "D" & 100 \\
LED 21 "E" & 100 \\
LED 22 "FELOPZD" & 100 \\
LED 23 DEFPOFEC" & 100 \\
\hline &
\end{tabular}

\section{DISCUSSION}

In this study, an examination and testing of the Android Snellen chart control were carried out. Tests were conducted to determine the ability of Bluetooth $\mathrm{HC}-05$ to send data to android at a distance of 10 meters. The test is carried out with 2 conditions, namely the first condition in one room without a barrier while the second condition is different from the room with a change in range every 2 meters. Tests for each distance range are carried out 5 times.
Based on the tests that have been done, the results show that the tool works well up to a distance of 10 meters. The level of button accuracy is also not experiencing problems.

\section{Conclusion}

This study has shown the development of the android Snellen control chart to facilitate the visual inspection process of the eye. This research was made with the Atmega 16 microcontroller using the 2803 ULN and Bluetooth HC05 lamp drivers to connect with Android. This study has proven its accuracy to be suitable for eye examination. In the future, this research can be made and used in the eye clinic.

\section{REFERENCES}

[1] R. T. Surya, "Snellen Chart Disertai Hasil Normal/Tidak Normalnya Ketajaman Penglihatan Berbasis Mikrokontroller," 2013.

[2] M. Sholihah, "Laporan Tugas Akhir Wireless Snellen Dengan Double Chart Dilengkapi Kontrol Pasien (Sistem Wireless),” 2014.

[3] S. H. Yunianto, "Laporan Tugas Akhir Wireless Snellen Dengan Double Chart Dilengkapi Kontrol Pasien (Kontrol Motor Dan Perpindahan Lampu," 2014. 